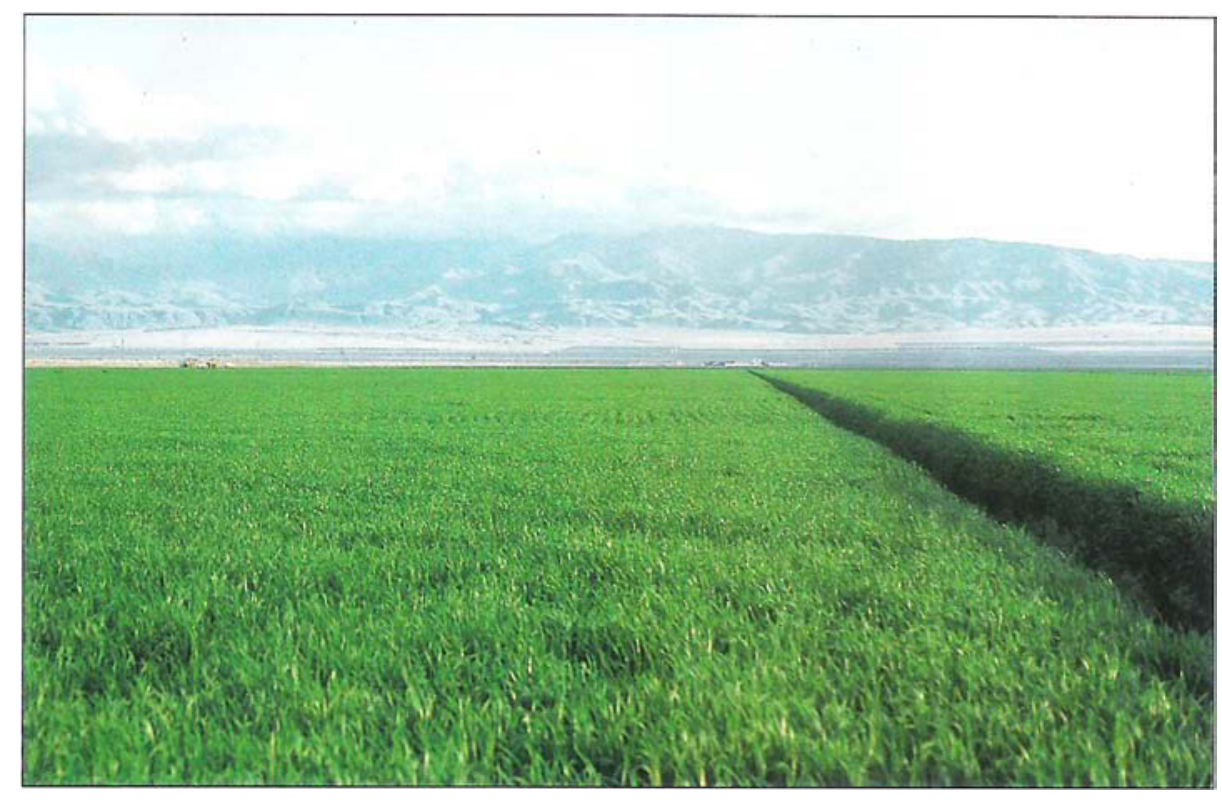

\title{
Late-season nitrogen may be efficient way to increase winter wheat protein
}

Left, Yecora Rojo wheat in Kern County. Below, wheat at flowering or anthesis. Yellow anthers are shedding pollen.

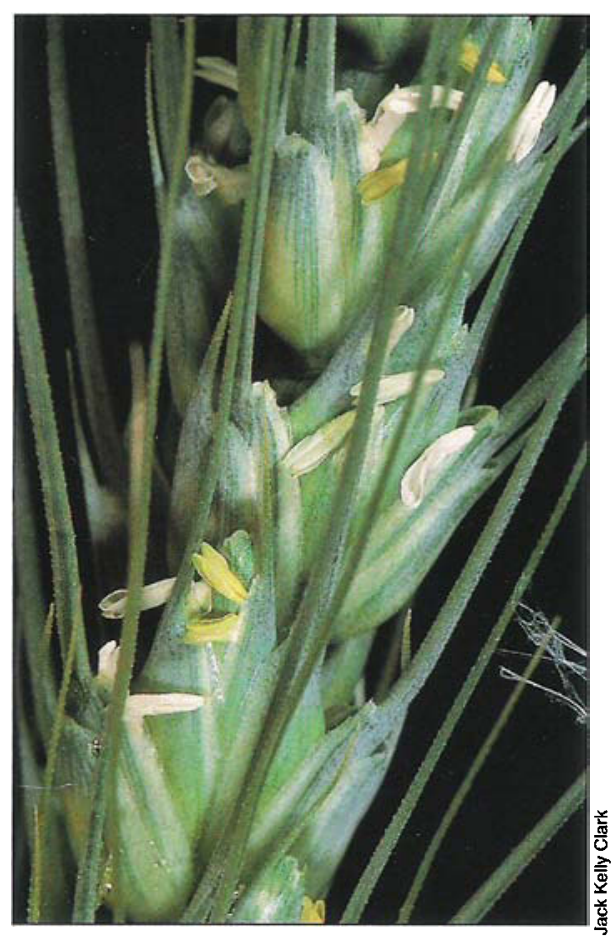

\section{Bruce A. Linquist $\square$ Ken G. Cassman a Allan E. Fulton $\square$ Lee F. Jackson}

\begin{abstract}
On-farm experiments were conducted throughout California to study the effect of early- and lateseason nitrogen fertilizer applications on grain protein in winter wheat. Results indicate that earlyseason nitrogen application is inefficient. However, late-season nitrogen $(N)$ applications coupled with irrigation can lead to efficient fertllizer $N$ uptake and partitioning to grain, and increased grain protein. Late-season application was not efficiently recovered in the grain when there was midseason nitrogen application or high native soil nitrogen supply.
\end{abstract}

Market demands for higher quality wheat have recently shifted in California. Because grain quality is largely a function of grain protein concentration (GPC) and protein synthesis depends on an adequate nitrogen (N) supply, management for protein must emphasize plant $\mathrm{N}$ nutrition. Because of increasing fertilizer costs and off- farm pollution caused by misuse of $\mathrm{N}$ fertilizer, efficient $\mathrm{N}$ management strategies must be developed. The purpose of this study was: (1) to study the effect of $\mathrm{N}$ fertilizer applied at planting and flowering (anthesis) in conjunction with irrigation on yield, GPC and N utilization efficiency and (2) to identify parameters at anthesis that predict grain yield, GPC, and N utilization efficiency so that the need and rate of late-season $\mathrm{N}$ application can be determined.

In the following discussion, "flowering" is used interchangeably with "anthesis," which means the specific time when anthers extrude from heads of wheat.

\section{Materials and methods}

Experiment 1. The effects of $\mathrm{N}$ fertilizer applied at anthesis on GPC and fertilizer-N uptake efficiency were examined in on-farm experiments throughout California in 1987-88 and 1988-89. Ten sites, six counties and two cultivars ('Yecora Rojo' and 'Klasic') were included in this study (table 1). The experiment consisted of two treatments placed in a randomized complete block design at each site. Treatments were $40 \mathrm{lb}$ N/ac uniformly broadcast as ammonium sulfate at flowering (+LN) and a control with no $N$ applied at flowering (-LN). Following this application, all fields were irrigated within 48 hours except Sac-1 where the grower decided not to irrigate due to 0.5 to 1 inch of rainfall the following day. At flowering, a composite soil sample collected from depths of 0 to 8 inches and 8 to 16 inches and a plant sample, which was partitioned into flag leaves and spikes, were taken from the (-LN) plots.

At physiological maturity, plant samples were harvested and partitioned into straw and grain fractions such that "straw" included stems, leaves and chaff. Yield and $N$ concentration were determined for both plant fractions. Soil samples were cooled immediately in an ice chest following sampling, then air-dried and sieved through a 2-mm screen. Soil measurements included $\mathrm{pH}, \mathrm{KCl}$-extractable $\mathrm{NH}_{4}-\mathrm{N}$ and $\mathrm{NO}_{3}-\mathrm{N}$, mineralizable $\mathrm{N}$ (10-day anaerobic mineralization), and total organic $N$ and carbon.

A similar 3-year study was conducted in Yolo County. Each year the preplant rate was $161 \mathrm{lb} \mathrm{N} /$ ac with -LN or +LN treatments at flowering (anthesis) identical to the on-farm experiments. These data are included with the on-farm data for regres- 
sion of soil parameters at flowering versus plant parameters at maturity.

Experiment 2. In 1988-89, a large field experiment was conducted to determine whether preplant $N$ rates could be reduced if a late-season $\mathrm{N}$ application was applied. The experiment was designed as a randomized complete block with two preplant $\mathrm{N}$ rates of 151 and $191 \mathrm{lb} \mathrm{N} / \mathrm{ac}$ and four replicates. Each plot contained 42 acres. 'Klasic' wheat was sown on January 1,1989 . Both treatments received supplemental $N$ of 60 and $54 \mathrm{lb} / \mathrm{ac}$ applied with irrigation at boot stage and 20 days before flowering, respectively. Plant samples were taken from four locations within each plot at boot stage (before the midseason $\mathrm{N}$ application), flowering and physiological maturity. Samples were treated as in experiment 1, except that at boot stage all the aboveground biomass was included in the straw fraction and the anthesis sample was partitioned into straw and spikes.

\section{Results and discussion}

Experiment 1. At flowering, spike and flag leaf $\mathrm{N}$ concentrations ranged from 1.7 to $2.3 \%$ and from 3.4 to $4.7 \%$ with means of 1.9 and $3.9 \%$, respectively. Kings- 1 and Kings-2 had the highest $N$ concentrations in the spike and flag leaf ( 2.3 and $2.2 \%$, respectively, for the spike and 4.5 and $4.7 \%$, respectively, for the flag leaf) due to midseason $\mathrm{N}$ applications at both sites (table 1). Extractable soil $\mathrm{NO}_{3}-\mathrm{N}$ was particularly high at Modoc, San Joaquin and Kings-2 due to multiple midseason $\mathrm{N}$ applications (Kings-2) or the high $\mathrm{N}$ mineralization capacity of the soil and large reserves of organic $\mathrm{N}$ and carbon (Modoc and San Joaquin) (table 1).

Grain yields ranged from 4,360 to 8,680 $\mathrm{lb} / \mathrm{ac}$ (table 2). Four sites had yields below $7,000 \mathrm{lb} / \mathrm{ac}$. Low yields were due to $\mathrm{N}$ stress (partially corrected with a midseason $\mathrm{N}$ application), weeds (Madera), late planting (Kings-2), earlyseason water stress (San Joaquin) and growing 'Yecora Rojo' in a climate where it was not well adapted (Modoc). At the other six sites grain yields were above $7,300 \mathrm{lb} / \mathrm{ac}$ and total fertilizer $\mathrm{N}$ applied before anthesis (preflowering) ranged from 90 to $226 \mathrm{lb} \mathrm{N} / \mathrm{ac}$. The wide range of preflowering $\mathrm{N}$ rates reflected the wide range of soil textures and inherent fertility, rotations, and area-specific cultural practices which may or may not lead to efficient $\mathrm{N}$ use.

Application of late-season $\mathrm{N}$ did not increase yields. However, other studies have shown small but significant increases in grain yield due to greater kernel size with late $\mathrm{N}$ applied with irrigation.

The +LN treatment resulted in an increase in grain $\mathrm{N}$ concentration (GNC) from 2.43 to $2.59 \%$ across sites (table 2).

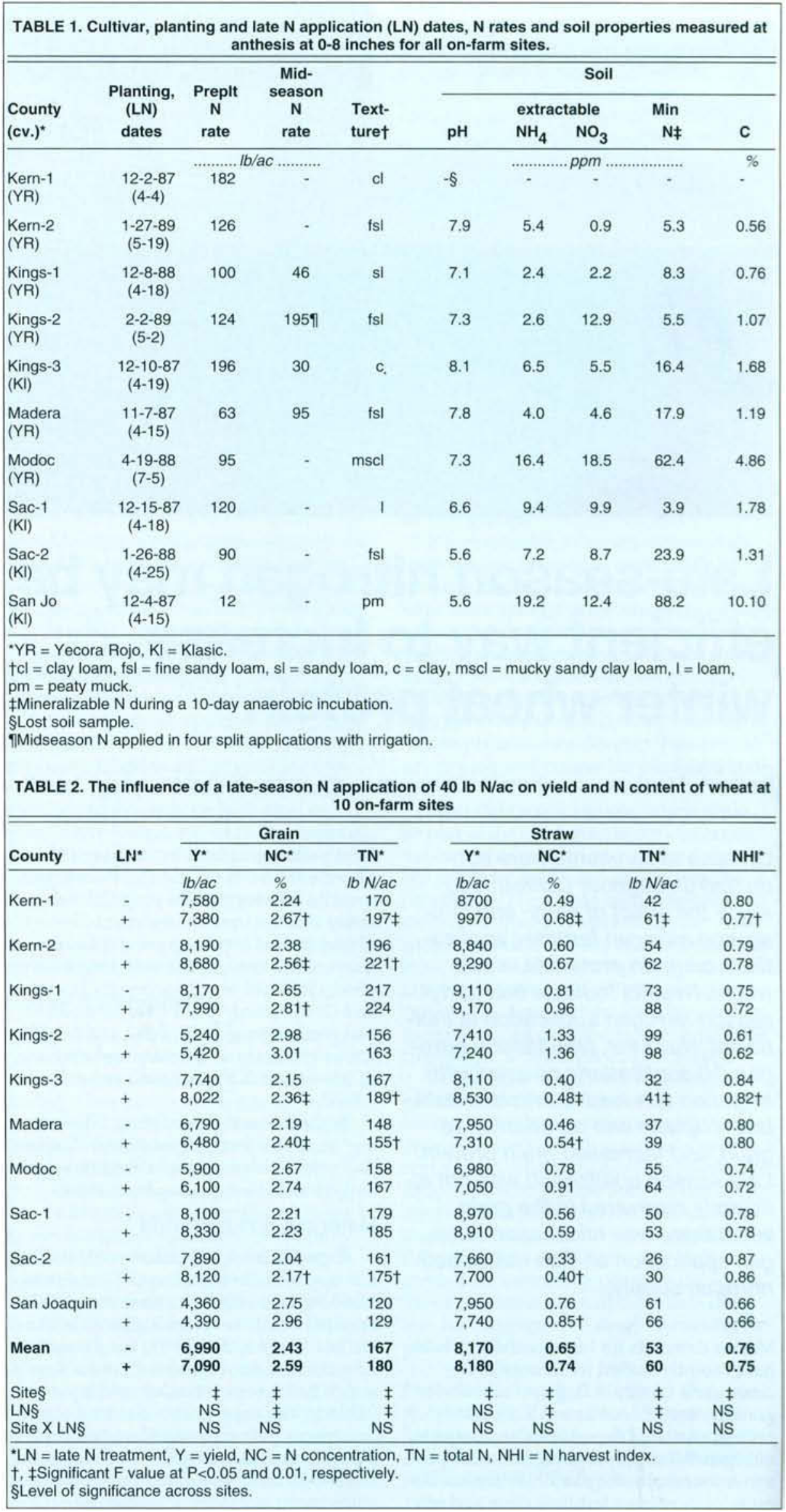


Assuming a target GPC of $13 \%$ protein at $12 \%$ moisture, the equivalent GNC, corrected for moisture, is $2.55 \%(\mathrm{GPC}=\mathrm{GNC}$ $\times 5.7$ ). At two of the six sites below target GNC in the -LN treatment, the late-season $\mathrm{N}$ application resulted in target GNC or greater (Kern-1 and Kern-2). These two sites had a mean GNC of $2.31 \%$ in the -LN plots, considerably higher than the mean of the other four sites, $2.15 \%$. Thus, at Kern- 1 and Kern -2 a smaller $N$ rate was required at flowering to reach target GNC.

At four sites (Sac-1, Kings-2, Modoc and San Joaquin) GNC did not significantly increase with the addition of supplemental $\mathrm{N}$ at flowering. At Sac-1 lack of irrigation following treatment application resulted in inefficient $\mathrm{N}$ uptake. The rainfall at Sac-1 was not enough to move the applied $\mathrm{N}$ into the zone of active root uptake. Studies have shown that late-season $\mathrm{N}$ deep in the soil profile (>6 inches) is taken up more efficiently than $\mathrm{N}$ near the surface.

The other three sites (Kings-2, Modoc and San Joaquin) reached the target GNC without supplemental $\mathrm{N}$ at flowering due to midseason $\mathrm{N}$ applications at Kings-2, or high soil $\mathrm{N}$ mineralization rates at Modoc and San Joaquin (table 1). These three sites and Kings-1 (in which GNC increased sig nificantly, but only slightly with late-season $\mathrm{N}$ ) indicate that high early-season or midseason $\mathrm{N}$ application results in inefficient partitioning of $\mathrm{N}$ to the grain.

Partitioning efficiency of $\mathrm{N}$ is reflected by the $\mathrm{N}$ harvest index (NHI) which is the proportion of plant $\mathrm{N}$ recovered in grain (table 2). When the early and \or midseason $\mathrm{N}$ supply from soil or fertilizer$\mathrm{N}$ was large, as at these sites, straw $\mathrm{N}$ concentration at maturity was high and the $\mathrm{NHI}$ was low. However, where straw $\mathrm{N}$ concentration was below $0.7 \%$, the $\mathrm{N}$ harvest index was high, ranging from 0.77 to 0.87 , indicating efficient $\mathrm{N}$ partitioning

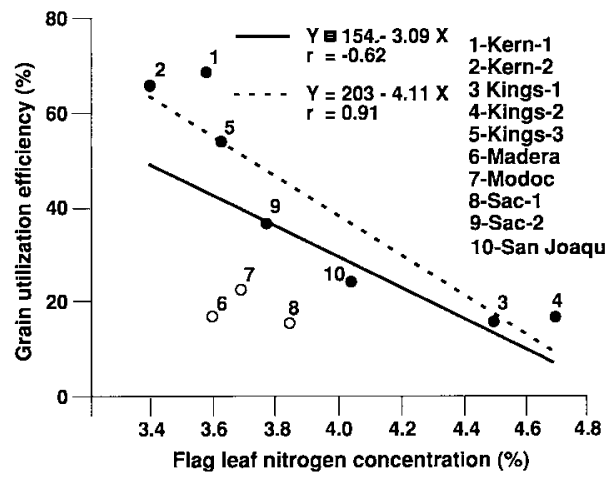

Fig. 1. The relationship between percent $\mathrm{N}$ applied at anthesis (flowering), which was allo cated to grain (GUE), and flag leaf nitrogen concentration at anthesis. The dashed line represents regression without inclusion of sites 6,7 and 8 , as discussed in text.

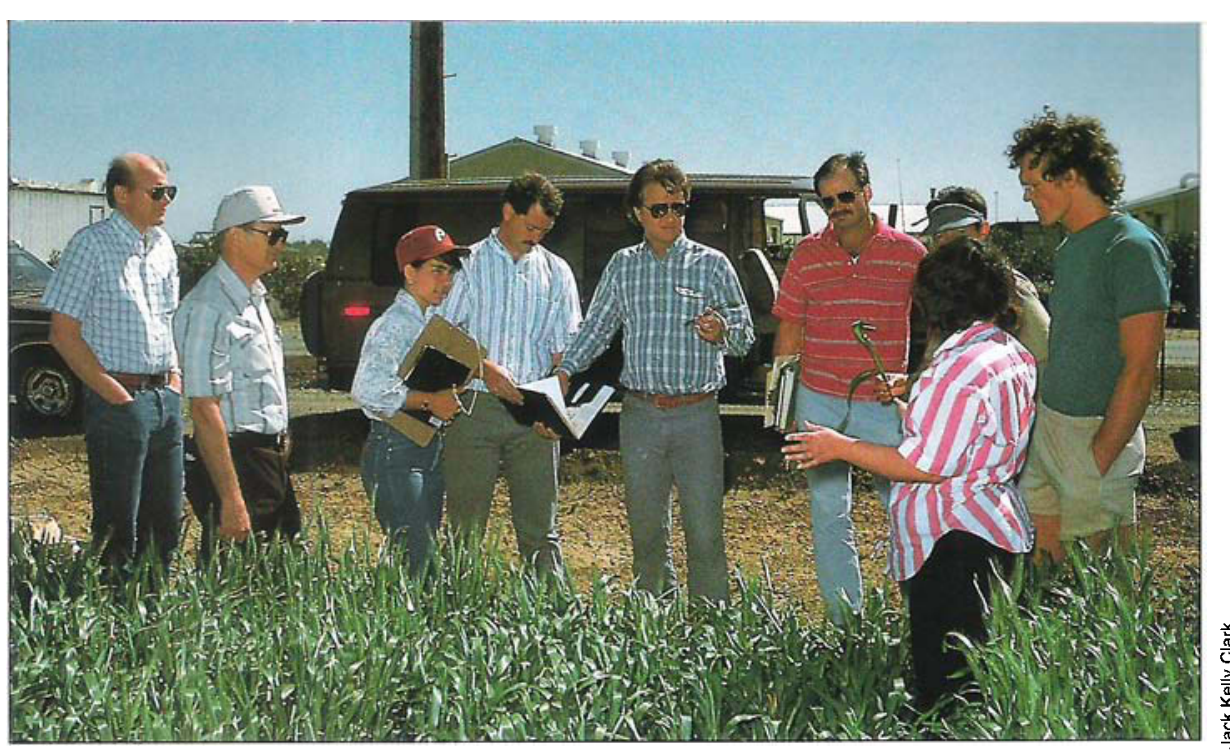

Ken Cassman talks to farm advisors about nitrogen application. From left to right are Larry Strand, Bill Weir, Wynette Sills, Mick Canevari, Ken Cassman, Lee Jackson, Marilyn Miller and Bruce Linquist.

such that 77 to $87 \%$ of plant $\mathrm{N}$ was harvested with grain.

Apparent uptake of the $\mathrm{N}$ applied at flowering (difference in total $\mathrm{N}$ uptake between the +LN and $-\mathrm{LN}$ ) ranged from 7 to $48 \mathrm{lb} \mathrm{N} / \mathrm{ac}$, equivalent to an uptake efficiency of 21 to $112 \%$ (table 3). Grain utilization efficiency (GUE is the percent $\mathrm{N}$ applied at flowering that is recovered in grain) ranged from 15 to $68 \%$. These two performance parameters were regressed against plant and soil parameters measured at flowering. Only two significant correlations were found, GUE versus flag leaf $\mathrm{N}$ concentration $(\mathrm{r}=-0.62, \mathrm{P}<0.05)$ (fig. 1) and apparent fertilizer-N uptake versus extractable nitrate- $\mathrm{N}(\mathrm{r}=-0.64$, $\mathrm{P}<0.05$ ) (fig. 2).

These relationships illustrate that earlyseason $\mathrm{N}$ management practices and soil $\mathrm{N}$ supply at flowering are important factors in determining $\mathrm{N}$ allocation to grain versus straw and fertilizer $\mathrm{N}$ uptake efficiency during grain filling. These correlations were stronger $(r=-0.91$ and $r=-0.89)$ when the Madera, Modoc and Sac- 1 sites

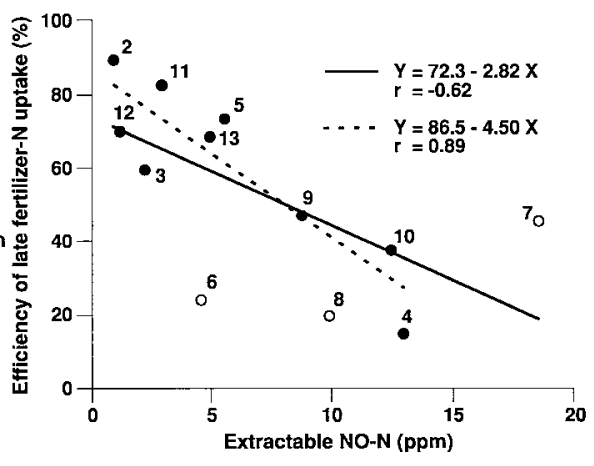

Fig. 2. The relationship between uptake efficiency of $\mathrm{N}$ fertilizer applied at anthesis and extractable soil $\mathrm{NO}_{3}-\mathrm{N}$ in the top 8 inches of soil at anthesis (flowering.) Included are three sites from a similar experiment in Yolo County $(11-13)$. The dashed line represents regression without inclusion of sites 6,7 and 8 . were excluded from the analysis due to (1) uneven stands and high weed pressure at Madera, (2) use of 'Yecora Rojo' which is not adapted to the Modoc location and (3) lack of irrigation following treatment application at Sac-1.

Kings- 1 was the only site that had a relatively high $\mathrm{N}$ uptake efficiency (55\%), but a low grain utilization efficiency (18\%) (table 3). This site had low soil nitrate-N and high flag leaf $\mathrm{N}$ levels at flowering (anthesis). The midseason $\mathrm{N}$ application resulted in the high plant $\mathrm{N}$ concentration, yet by flowering this added $\mathrm{N}$ was not detected in soil nitrate levels.

During grain filling the Kings-1 crop maintained an active root system; thus, late-season fertilizer- $\mathrm{N}$ uptake efficiency was relatively high at this site (table 4). However, the high plant $\mathrm{N}$ concentration governed the partitioning efficiency such that most of the increased plant $N$ from the late-season application was partitioned to straw. The hypothesis that soil $\mathrm{N}$ levels govern uptake efficiency from late $\mathrm{N}$ application is supported by the relationship shown in figure 2, whereas the influence of plant $\mathrm{N}$ status on $\mathrm{N}$ partitioning efficiency is evident from the NHI values in table 2 and the relationship shown in figure 1.

One of the objectives of this experiment was to identify parameters at flowering that would predict the yield and GNC of the crop at maturity. Yield and GNC at maturity were regressed against plant tissue (spike and flag leaf) and soil parameters taken at flowering. Flag leaf and spike $\mathrm{N}$ concentrations were positively correlated with GNC ( $\mathrm{r}=0.72$ and 0.68 , respectively), but grain yield was not correlated with the measured flowering parameters. Both GNC and yield are required to estimate late $\mathrm{N}$ requirements.

The ability to estimate the quantity of $\mathrm{N}$ to apply at flowering would increase the economic return from $\mathrm{N}$ fertilization and reduce the potential for $\mathrm{N}$ losses. For 
example, at Kern-2, if a yield of $8,200 \mathrm{lb} / \mathrm{ac}$ with a GNC of $2.38 \%$ was expected, the grain in the crop would require an additional $14 \mathrm{lb} \mathrm{N} / \mathrm{ac}$ at flowering to reach the target GNC (2.55\%). With a GUE of $63 \%$ at this site (table 3), an application of $22 \mathrm{lb}$ $\mathrm{N} /$ ac would be adequate.

Despite not identifying parameters at flowering that would allow for an estimation of late $\mathrm{N}$ requirements, two parameters were identified that may be useful in determining whether a late $N$ application is necessary to achieve target protein lev- els. In this experiment, sites having greater than $4 \% \mathrm{~N}$ in the flag leaf or $10 \mathrm{ppm} \mathrm{ni-}$ trate- $\mathrm{N}$ in the soil at flowering did not require the additional $\mathrm{N}$ to reach target GNC. However, where early-season N management resulted in low extractable soil $\mathrm{N}$ or flag leaf $\mathrm{N}$ concentration, our results indicate that application of $\mathrm{N}$ at flowering would be an effective option to raise GPC levels to the desired threshold even at high yield levels. For example, the Kern-2 site had the lowest flag leaf and soil nitrate- $\mathrm{N}$ levels but $\mathrm{N}$ uptake effi-

TABLE 3. Plant $\mathrm{N}$ accumulation, uptake efficiency and utilization efficiency from late season $\mathrm{N}$ application in the on-farm sites

\begin{tabular}{|c|c|c|c|c|c|c|}
\hline \multirow[b]{2}{*}{ Site } & \multirow[b]{2}{*}{$\stackrel{+/-}{\text { Late } \mathrm{N}}$} & \multirow[b]{2}{*}{ TFN $^{*}$} & \multirow[b]{2}{*}{$\mathrm{TN}^{*}$} & \multirow{2}{*}{$\begin{array}{c}\text { Apparent } \\
\text { late } N \\
\text { uptake* }\end{array}$} & \multicolumn{2}{|c|}{ Efficiency } \\
\hline & & & & & $\begin{array}{l}\text { Late } N \\
\text { uptake* }\end{array}$ & $\begin{array}{c}\text { Grain } \\
\text { utilization* }\end{array}$ \\
\hline Kern-1 & $\dot{+}$ & $\begin{array}{l}182 \\
222\end{array}$ & $\begin{array}{l}\text { Nac } \\
211 \\
257 \mp\end{array}$ & 46 & 112 & ........ \\
\hline Kern-2 & . & $\begin{array}{l}126 \\
166\end{array}$ & $\begin{array}{l}248 \\
284 \dagger\end{array}$ & 36 & 90 & 63 \\
\hline Kings-1 & $\dot{4}$ & $\begin{array}{l}146 \\
186\end{array}$ & $\begin{array}{l}290 \\
312\end{array}$ & 22 & 55 & 18 \\
\hline Kings-2 & - & $\begin{array}{l}320 \\
360\end{array}$ & $\begin{array}{l}255 \\
262\end{array}$ & 7 & 18 & 18 \\
\hline Kings-3 & i & $\begin{array}{l}226 \\
268\end{array}$ & $\begin{array}{l}199 \\
2307\end{array}$ & $3^{+}$ & 78 & 55 \\
\hline Madera & + & $\begin{array}{l}158 \\
198\end{array}$ & $\begin{array}{l}185 \\
195 t\end{array}$ & 10 & 25 & 18 \\
\hline Modoc & $\dot{+}$ & $\begin{array}{r}95 \\
135\end{array}$ & $\begin{array}{l}213 \\
231\end{array}$ & 18 & 45 & 23 \\
\hline Sac-1 & i & $\begin{array}{l}120 \\
160\end{array}$ & $\begin{array}{l}229 \\
238\end{array}$ & $g$ & 23 & 15 \\
\hline Sac-2 & $\dot{+}$ & $\begin{array}{r}90 \\
130\end{array}$ & $\begin{array}{l}187 \\
205 \dagger\end{array}$ & 18 & 45 & 35 \\
\hline San Jo & i & $\begin{array}{l}11 \\
51\end{array}$ & $\begin{array}{l}180 \\
196\end{array}$ & 16 & 40 & 23 \\
\hline mean & $\dot{+}$ & $\begin{array}{l}147 \\
210\end{array}$ & $\begin{array}{l}220 \\
241 \ddagger\end{array}$ & 21 & 53 & 34 \\
\hline
\end{tabular}

- TFN=total fertilizer $\mathrm{N}$ and $T \mathrm{~N}=$ total $\mathrm{N}$ accumulation in aboveground biomass. Late $\mathrm{N}$ uptake effic ency = apparent late-season $\mathrm{N}$ uptake divided by the amount of ate-season $\mathrm{N}$ applied. Grain utlization efficency $=$ the percentage of fertilizer- $\mathrm{N}$ app.ied that was recovered in the grain

†. $\mp$ Significant differences within sites or across sites due to $\mathrm{N}$ application at anthesis. $\mathrm{P}<0.05$ and 0.01 , respectively.

TABLE 4. Yield, $N$ concentration and incremental uptake efficiency of preplant $N$ at boot stage in experiment 2. At boot stage all the aboveground plant biomass was included in the straw fraction

\begin{tabular}{|c|c|c|c|c|c|c|c|c|c|}
\hline \multirow[b]{2}{*}{ PP* } & \multicolumn{3}{|c|}{ Grain } & \multicolumn{3}{|c|}{ Straw } & \multicolumn{3}{|c|}{ Uptake } \\
\hline & $Y^{*}$ & $\mathrm{NC}^{*}$ & $\mathrm{TN}^{*}$ & $\mathrm{Y}^{\star}$ & $\mathrm{NC}^{*}$ & $\mathrm{TN}^{*}$ & $\mathrm{TN}^{*}$ & eff., ${ }^{*}$ & $\mathrm{NHI}^{*}$ \\
\hline & \multicolumn{8}{|c|}{ Boot stage } & \\
\hline 151 & . & . & . & 4,236 & 3.24 & 138 & 138 & - & . \\
\hline 191 & - & - & - & 4,329 & 3.38 & 146 & 146 & 20 & - \\
\hline $\begin{array}{l}\text { Analysis } \\
\text { of variance }\end{array}$ & & & & NS & $\ddagger$ & $\ddagger$ & $\ddagger$ & & \\
\hline \multicolumn{10}{|c|}{ Maturity } \\
\hline 151 & 8.032 & 2.54 & 204 & 7.692 & 0.62 & 48 & 252 & - & 0.81 \\
\hline 191 & 7,766 & 2.62 & 204 & 8,012 & 0.71 & 56 & 260 & 20 & 0.78 \\
\hline $\begin{array}{l}\text { Analysis } \\
\text { of variance }\end{array}$ & $\dagger$ & $\dagger$ & NS & NS & $\div$ & $\ddagger$ & NS & & $\ddagger$ \\
\hline
\end{tabular}

-PP preplant $\mathrm{N}$ rate. $\mathrm{Y}$ - yield, $\mathrm{NC}=\mathrm{N}$ concentration, and $\mathrm{TN}=$ total plant $\mathrm{N}, \mathrm{NHI}=\mathrm{N}$ harvest index and NS = not significant. Uptake efficiency is the difference between plant $N$ uptake in the two preplant rates divided by the cifference in preplant rates

$\dagger, \neq$ indicate a significant $F$ value at $P<0.05$ and 0.01 , respectively.

ciency and GUE from late $\mathrm{N}$ application were high (table 3 ) and target GNC was exceeded in the +LN treatment (table 2).

Experiment 2. At boot stage, wheat that received the high preplant $\mathrm{N}$ rate had higher tissue $\mathrm{N}$ concentration and had accumulated $8 \mathrm{lb} \mathrm{N} /$ ac more than wheat fertilized at the low preplant rate (table 4). The incremental fertilizer- $\mathrm{N}$ uptake efficiency from the additional $40 \mathrm{lb}$ N/ac preplant $\mathrm{N}$ was $20 \%$. At flowering (anthesis), the difference in plant $\mathrm{N}$ accumulation for the two preplant $\mathrm{N}$ rates was the same as at boot stage, suggesting that any difference in soil $\mathrm{N}$ supply from the greater preplant $\mathrm{N}$ rate had disappeared by boot stage.

At maturity, lower grain yields in the high preplant treatment were probably due to increased lodging. Both preplant rates resulted in target GNC, although GNC was slightly higher for the high preplant rate. Because $\mathrm{N}$ accumulation in the grain was the same for both treatments, the higher GNC was due to protein dilution by the higher yields in the low preplant treatment.

The preplant rate affected $\mathrm{N}$ partitioning patterns during grain filling. Under both $\mathrm{N}$ regimes, the plant partitioned an equal quantity of $\mathrm{N}$ to grain; however, proportionately more $\mathrm{N}$ was partitioned to the grain at the low preplant rate. The additional $8 \mathrm{lb} \mathrm{N} /$ ac taken up by wheat in the high preplant $\mathrm{N}$ rate treatment was partitioned to the straw fraction (table 4).

\section{Conclusion}

Early season $\mathrm{N}$ management should only attempt to optimize yields. Experiment 2 clearly illustrates that reliance on increased rates of preplant $N$ to achieve threshold grain protein levels is inefficient, whereas $\mathrm{N}$ applications at flowering, coupled with irrigation can efficiently increase GNC. Excessive early-season N rates, multiple midseason $\mathrm{N}$ applications or high native soil $\mathrm{N}$ mineralization potential limits the efficacy and need for late $\mathrm{N}$ application. Moreover, excessive $\mathrm{N}$ supply from soil or fertilizer in the early season results in inefficient $\mathrm{N}$ partitioning to grain. None of the soil or plant parameters measured at flowering accurately predicted grain yield at maturity. However, flag leaf $N$ concentration was positively correlated with GNC and negatively correlated with grain utilization efficiency, and soil nitrate- $\mathrm{N}$ at flowering was negatively correlated with $\mathrm{N}$ uptake efficiency from late-season $\mathrm{N}$ application.

B. A. Linquist is Graduate Student and K. G. Cassman is Associate Professor, Department of Agronomy and Range Science, UC Davis; $A$. E. Fulton is Soils and Water Farm Advisor, Kings County, and L. F. Jackson is Extension Agronomist, UC Davis. 